\title{
O VALOR JURÍDICO DOS TRATADOS INTERNACIONAIS DE DIREITOS HUMANOS NO BRASIL: ANÁLISE DE SUA POSIÇÃO NA HIERARQUIA DAS FONTES A PARTIR DO JULGAMENTO DO RECURSO EXTRAORDINÁRIO 466.343-1/SP PELO SUPREMO TRIBUNAL FEDERAL E DA DOUTRINA DO DIREITO INTERNACIONAL
}

\section{The Legal Value of International Treaties on Human Rights in Brazil: Analysis of its position in sources hierarchy from Supreme Court Extraordinary Appeal Judgment 466.343-1/SP by Federal Supreme Court and the Doctrine of International Law ${ }^{1}$}

Thiago Moreira Feitosa de Aguiar²

\begin{abstract}
Sumário: 1 Introdução. 2 Aspectos da literatura jurídica internacional. 3 Panorama do RE 466.343-1/SP julgado pelo Supremo Tribunal Federal. 4 Análise das teses acerca dos tratados internacionais. 4.1 $\mathrm{O}$ voto do Ministro Gilmar Mendes: a vencedora tese da supralegalidade. 4.2 Voto do Ministro Celso de Mello: status constitucional dos tratados humanitários. $4.3 \mathrm{O}$ voto do Ministro Menezes Direito: o caráter especial dos tratados humanitários. 5. Análise crítica do entendimento do Supremo Tribunal Federal à luz da doutrina do direito internacional. 6 Conclusão. Referências.
\end{abstract}

\begin{abstract}
Resumo: Em 2008, houve o julgamento do RE 466.343-1/SP pelo Supremo Tribunal Federal, mudando seu entendimento tradicional. Para esta Corte, aos tratados internacionais de direitos humanos, no Brasil, é conferido status supralegal, mas infraconstitucional, mantendo-se no ápice do ordenamento a Constituição. Porém, há divergências acerca deste entendimento da hierarquia das fontes, sobretudo em relação ao monismo internacionalista. O presente artigo propõe uma análise crítica da decisão judicial pela ótica da doutrina internacionalista.
\end{abstract}

Palavras-chave: Status dos tratados internacionais de direitos humanos no Brasil. O entendimento do Supremo Tribunal Federal. A crítica do monismo internacionalista.

\begin{abstract}
In 2008 there was the trial of RE 466343-1/SP by the Federal Supreme Court changing its traditional understanding. For the Court the international human rights treaties, in Brazil, is given supra-legal status, but infraconstitutional, keeping itself in the Constitution apex. However, there are disagreements on this sources hierarchy understanding, particularly in relation to the internationalist monism. This article proposes a critical analysis of the judicial decision by the internationalist doctrine perspective.
\end{abstract}

Key-words: International human rights treaties status in Brazil. The Understanding Federal Supreme Court. The monism's internationalist criticism.

\section{INTRODUÇÃO}

Em 2008, o Supremo Tribunal Federal (STF) revisitou o entendimento da Corte3, em sede de recurso extraordinário, pela compreensão de que inexistia suporte infraconstitucional para a prisão civil do depositário infiel, uma vez

\footnotetext{
${ }^{1}$ DOI deste artigo: http://dx.doi.org/10.12957/cosmopolitan.2014.11934.

${ }^{2}$ Graduando em Direito (Bacharelado) pela Universidade Estadual do Maranhão (UEMA).

3 Tradicionalmente defensor da tese da legalidade dos tratados internacionais, a qual se remonta ao julgamento, pelo STF, do RE ${ }^{\circ}$ 80.004/SE (Min. Rel. Xavier de Albuquerque, julgado em 1/6/77, DJ de 29/12/77).
} 
internamente assentada a Convenção Americana sobre Direitos Humanos de 1969 (CADH) - Pacto de São José da Costa Rica - e o Pacto Internacional sobre Direitos Civis e Políticos, parâmetros normativos supralegais que paralisaram a disposição legal que permitia o rito da ação de depósito ao devedor fiduciante.

O Pacto de São José da Costa Rica4 foi promulgado no Brasil por via do Decreto $n^{\circ} 678$ de 6 de novembro de 1992. Tal diploma internacional prescreve que "ninguém deve ser detido por dívidas. Este princípio não limita os mandados de autoridade judiciária competente expedidos em virtude de inadimplemento de obrigação alimentar" (artigo $7^{\circ}$, item 7).

Ao seu turno, o Pacto Internacional sobre Direitos Civis e Políticos5, adotado pela XXI Sessão da Assembleia-Geral das Nações Unidas, em 16 de dezembro de 1966, foi promulgado no Brasil por meio do Decreto $\mathrm{n}^{\circ} 592$ de 6 de julho de 1992, prescrevendo em seu artigo 11 que "ninguém poderá ser preso apenas por não poder cumprir com uma obrigação contratual”.

Destarte, de acordo com a nova posição do STF, não subsistia a previsão constante no artigo $4^{\circ}$ do Decreto-Lei ${ }^{\circ} 911$ de 1969, a qual equiparava o devedor fiduciante ao infiel depositário, de modo a permitir sua prisão civil caso não fosse entregue o bem, seguindo-se o rito da ação de depósito em razão de tal equiparação ${ }^{6}$.

Para a tese vencedora no Supremo Tribunal Federal, pertencente ao Ministro Gilmar Mendes, os tratados internacionais de direitos humanos, como a Convenção Americana e o Pacto Internacional, possuem status supralegal, mas infraconstitucional, na hierarquia das fontes brasileira, de modo que esta tese impõe reconhecer que o sistema de controle de normatividade no âmbito doméstico passou a apresentar mais um patamar de controle de compatibilidade vertical para a legislação interna ordinária (os tratados humanitários).

4 Conferir BRASIL. Convenção Americana Sobre Direitos Humanos. Disponível em: <http://www.planalto.gov.br/ccivil_o3/decreto/1990-1994/anexo/and678-92.pdf>. Acesso em: 29/05/2014.

5 Conferir BRASIL. Pacto Internacional dos Direitos Civis e Políticos. Disponível em: <http://www.planalto.gov.br/ccivil_03/decreto/1990-1994/Do592.htm >. Acesso em: 29/05/2014.

${ }^{6}$ Conforme possibilitavam os artigos 367 a 369 do vetusto Decreto-Lei ${ }^{\circ} 1.608$ de 1939 (Código de Processo Civil de 1939) e 1.287 do vetusto Código Civil de 1916 (Lei 3.071 de 1916) e 652 do Código Civil atual (Lei 10.406 de 2002) e os artigos 902 a 904 do Código Processual Civil atual (Lei ${ }^{\circ} 5.869$ de 1973). 
Tal posição opôs-se à exposta pelo Min. Celso de Mello, a qual compreendia que tais tratados e convenções possuem qualificação constitucional, bem como pelo Min. Menezes Direito que os entendia com caráter de "lei especial", isto é, com natureza de atos normativos de hierarquia diferenciada, os quais se situariam no plano da legalidade, mas que se elevariam diante da produção normativa doméstica7.

De tal modo, a compreensão da hierarquia dos tratados internacionais de direitos humanos conferiu primazia ao direito nacional, uma vez tida como base a supremacia formal e material da Constituição da República Federativa do Brasil (CRFB), definida como parâmetro de qualificação jurídica dos pactos da comunidade internacional com o Brasil.

Contudo, é possível identificar correntes da literatura do direito internacional que sustentam entendimentos distintos do firmado no STF acerca da relação entre o direito internacional e o direito doméstico, inclusive sobre qual consistiria no fundamento de validade do ordenamento, o que tem consequências na hierarquia das fontes tal como foi delineada no julgamento em tela.

Diante disto, objetiva-se examinar a hierarquia dos tratados internacionais de direitos humanos no Brasil, observando-se a decisão do STF no RE 466.3431/SP e a compreensão da literatura jurídico-internacionalista sobre o tema, sobretudo ao monismo que confere primazia ao direito internacional. Para tanto, pretende-se: analisar as teses dos Ministros do Supremo Tribunal Federal relacionadas ao assunto, expor os entendimentos doutrinários distintos da tese vencedora e refletir acerca das consequências da adoção da tese da supralegalidade.

\section{ASPECTOS DA LITERATURA JURÍDICA INTERNACIONALISTA}

Questão datada desde o início do estudo sobre o direito internacional, relacionada ao seu fundamento, é a referente à sua eficácia e aplicabilidade na ordem jurídica interna dos Estados. Ela traduz-se na sistematização das relações entre o direito internacional público e o direito interno estatal, situando a problemática no exame acerca da hierarquia conferida às fontes do direito, bem

7 Conferir o voto do Min. Menezes Direito, página 1303 do RE (p. 18 do voto). 
como da solução de eventuais conflitos normativos entre disposições internas e internacionais convergentes.

Nesse sentido, apesar das variações, verifica-se duas grandes correntes na literatura jurídico-internacionalista ${ }^{8}$ : a corrente dualista (cindida entre dualismo radical e moderado) e a corrente monista (nacionalista/internacionalista ou radical/moderada). A questão é "se o direito internacional e o direito interno são dois ordenamentos independentes, estanques, ou dois ramos de mesmo sistema jurídico. A primeira solução é defendida pelos partidários da tese monista, ao passo que a tese oposta é denominada dualista"9.

Para o dualismo ${ }^{10}$, os sistemas do direito internacional e do direito interno seriam distintos, independentes/separados, não convergentes. Neste viés, respectivamente, "salientam que num caso se trata de relações entre estados, enquanto, no outro, as regras visam à regulamentação das relações entre indivíduos"11. Noutros termos:

o Direito interno de cada Estado e o Direito Internacional são dois sistemas independentes e distintos, ou seja, constituem círculos que não se interceptam (meramente contíguos), embora sejam igualmente válidos. As fontes e normas do Direito Internacional (notadamente os tratados) não têm, para os dualistas, qualquer influência sobre questões relativas no âmbito do Direito interno, e vice-versa, de sorte que entre ambos os ordenamentos jamais poderia haver conflitos. ${ }^{12}$

Destarte, o compromisso exterior do Estado restringe-se ao direito internacional, sem qualquer impacto no cenário jurídico doméstico até que seja adotado como lei interna, pelo fenômeno da transformação ${ }^{13}$. Em caso de omissão nesta tarefa, a sanção seria tão somente a responsabilidade internacional do Estado $^{14}$. Assim, não havendo identidade de fontes e por regularem matérias diferentes, não se poderia falar em conflito ou necessidade de escalonamento de fontes, para o dualismo. Tal era o dualismo radical.

\footnotetext{
8 Conforme ACCIOLY, Hildebrando; SILVA, G. E. do Nascimento e; CASELLA, Paulo Borba. Manual de direito internacional público. 20 ed. São Paulo: Saraiva, 2012. p. 237-239. MAZZUOLI, Valério de Oliveira. Curso de direito internacional público. $8^{\mathrm{a}}$ ed. rev., atual. e ampl. São Paulo: Editora Revista dos Tribunais, 2014. p. 85-104. VERDROSS, Alfred. O fundamento do direito internacional. Revista de Direito Internacional. Uniceub. Brasília, v. 10, n. 2, 2013, 18-33.

9 ACCIOLY; SILVA; CASELLA, 2012, p. 237.

1o Preconizado por Henrich Triepel, em feições radicais, conforme ACCIOLY; SILVA; CASELLA (2012, p. 238) e VERDROSS (2013, p. 19).

${ }^{11}$ Idem, ibidem.

${ }^{12}$ MAZZUOLI, 2014, p. 87.

${ }^{13}$ ACCIOLY; SILVA; CASELLA, op. cit., p. 237. MAZZUOLI, op. cit., p. 87.

14 Cf. MAZZUOLI, op. cit., p. 89.

76 Cosmopolitan Law Journal, v. 2, n. 1, jun. 2014, p. 73-94
} 
Posteriormente, verteu-se o dualismo para uma feição moderada ${ }^{15}$, na qual se "permitia que, em certos casos, o Direito Internacional fosse aplicado internamente pelos tribunais, sem que houvesse uma recepção formal do tratado na ordem interna"16. A incorporação do direito internacional internamente "prescindiria de lei, embora se faça mediante procedimento complexo e promulgação executiva"17.

Não obstante, observa-se ainda a corrente monista ${ }^{18}$. Nesta, parte-se de um fundamento único superior, para o qual o direito interno e o internacional são dois ramos do mesmo sistema, de modo que:

o Direito Internacional se aplica diretamente na ordem jurídica dos Estados, independentemente de qualquer "transformação", uma vez que esses mesmos Estados, nas suas relações com outros sujeitos do direito das gentes, mantêm compromissos que se interpenetram e que somente se sustentam juridicamente por pertencerem a um sistema jurídico uno, baseado na identidade de sujeitos (...) e de fontes (...). ${ }^{19}$

Sustentada essa premissa, surge a questão de qual ordem deve prevalecer em caso de conflito. A resposta teórica, a depender da variação da corrente, confere primazia ao direito nacional (monismo nacionalista) ou ao direito internacional (monismo internacionalista). Para o monismo nacionalista, o "Direito Internacional não seria mais que uma consequência do Direito interno"2o. Predomina, nesse sentido, o princípio da supremacia da Constituição e da vontade soberana absoluta do Estado.

Já o monismo internacionalista ${ }^{21}$ advoga que o direito interno retira seu fundamento de validade do direito internacional, o qual representa uma ordem jurídica hierarquicamente superior, prevalecendo sobre o primeiro. Nesse sentido, o direito internacional repousa sobre o edifício do pacta sunt servanda que obriga os Estados a se conformarem às regras criadas entre eles, reforçando a concepção de comunidade internacional22 (sua modificação exige necessariamente a dinâmica da sociedade internacional).

\footnotetext{
${ }^{15}$ Sendo os seus maiores expoentes Dionisio Anzilotti e Lassa Oppenheim, conforme MAZZUOLI (2014, p. 89).

${ }^{16}$ Idem, ibidem.

${ }_{17}$ Cf. ACCIOLY; SILVA; CASELLA, op. cit., p. 238.

${ }_{18}$ Tendo em Hans Kelsen o seu maior expoente, conforme MAZZUOLI (2014, p. 93).

19 MAZZUOLI, op. cit., p. 93.

${ }^{20}$ Idem, p. 95.

${ }^{21}$ Desenvolvido pela Escola de Viena (Kelsen, Verdross e Josef Kunz), conforme MAZZUOLI (2014, p. 97).

${ }^{22}$ Nesse sentido: VERDROSS, 2013, p. 18.

Revista de Direito Internacional do Programa de Pós-Graduação em Direito da UERJ 77
} 
O monismo que confere primazia ao direito internacional relativiza a soberania (tradicionalmente absoluta), considerando que a competência da comunidade internacional é juridicamente ilimitada (competência da competência), utilizando-se o direito interno para intermediar seus desígnios ${ }^{23}$.

$\mathrm{O}$ monismo é ainda observado pelas vertentes radical e moderado. $\mathrm{O}$ radical prega a primazia dos tratados sobre a ordem jurídica interna ${ }^{24}$, ao passo que, o monismo moderado não prega nem a "prevalência do Direito Internacional sobre o Direito Interno, nem a do Direito Interno sobre o Direito Internacional, mas a concorrência entre ambas as ordens jurídicas, determinando-se a prevalência de uma em relação à outra pelo critério cronológico"25.

Deste modo, a lei posterior (interna ou internacional) revoga a anterior (internacional ou doméstica) pela regra later in time. Há ainda, vale observar, uma derivação do monismo denominada de internacionalista dialógico, o qual, tendo em vista que o monismo internacionalista confere tratamento indistinto às normas internacionais em relação ao seu conteúdo substancial, defende "um 'diálogo' entre as fontes de proteção internacional e interna, a fim de escolher qual a 'melhor norma' a ser aplicada no caso concreto" 26.

Nessa esteira, em relação às normas internacionais de direitos humanos, haveria uma autorização para que se aplique a norma mais favorável (pro homine), seja ela de direito interno ou de direito internacional, consubstanciada em dispositivos ("vasos comunicantes"/"cláusulas de diálogo") internacionais, como ocorre no artigo 29, alínea "b", da Convenção Americana sobre Direitos Humanos ${ }^{27}$.

\section{PANORAMA DO RE 466.343-1/SP JULGADO PELO SUPREMO TRIBUNAL FEDERAL}

O STF delineou novo entendimento acerca do status dos tratados internacionais de direitos humanos na hierarquia das fontes do direito brasileiro

\footnotetext{
23 Idem, p. 18-33.

${ }^{24}$ Cf. ACCIOLY; SILVA; CASELLA, op. cit., p. 239.

25 MAZZUOLI, op. cit., p. 99.

${ }^{26}$ MAZZUOLI, op. cit., p. 102.

${ }^{27} \mathrm{CADH}$, art. 29. "Normas de interpretação: Nenhuma disposição desta Convenção pode ser interpretada no sentido de: b) limitar o gozo e exercício de qualquer direito ou liberdade que possam ser reconhecidos em virtude de leis de qualquer dos Estados-partes ou em virtude de Convenções em que seja parte um dos referidos Estados." 
com o julgamento do Recurso Extraordinário 466.343-1/São Paulo, da relatoria do Min. Cezar Peluso, em 03 de dezembro de 2008 (DJe n ${ }^{\circ}$ 104, publicado em 05/06/2009) ${ }^{28}$, servindo de parâmetro para os demais entendimentos da Corte $^{29}$.

$\mathrm{Na}$ ocasião, três votos enfatizaram a análise do status dos tratados humanitários no Brasil, aqueles pertencentes aos Mins. Gilmar Mendes, Celso de Mello e Menezes Direito. Os outros votos detiveram-se na análise da natureza jurídica do devedor fiduciante, notadamente se é constitucional equipará-lo ao fiel depositário. Dessarte, será relatado o iter do Recurso Extraordinário (RE), com foco aos votos que abordaram aos status dos tratados humanitários no Brasil.

O RE em tela fora interposto pelo Banco Bradesco S/A contra acórdão do Tribunal de Justiça de São Paulo que, em sede de apelação, confirmou a procedência de ação de depósito, fundada em alienação fiduciária em garantia, mas que deixou de determinar a prisão civil ao devedor fiduciante, caso não fosse entregue o bem, como requereu o recorrente, pela compreensão da inconstitucionalidade da prisão civil. O recurso extraordinário foi admitido e conhecido, mas teve seu provimento negado por unanimidade.

O Relator examinou a matéria pela ótica das disposições legais que equipararam o devedor fiduciante ao depositário infiel 30 , tendo em vista o permissivo constitucional da prisão civil do segundo ${ }^{31}$, expondo o entendimento de que não há similitude jurídica entre os institutos do depósito e da alienação fiduciária, uma vez que a obrigação de guardar para restituir é o conteúdo econômico-social do primeiro, sem qualquer acessoriedade da custódia,

\footnotetext{
${ }^{28}$ Disponível no site do STF: <http://redir.stf.jus.br/paginadorpub/paginador.jsp?docTP= AC\&docID $=595444>$. Acesso em 29/05/2014.

29 Como no RE 87.585-8 TO, Rel. Min. Marco Aurélio, julgado conjuntamente com o RE sub examine em 03/12/2008 (DJe $\mathrm{n}^{\circ}$ 118, publicação em 26/o6/2009) e no RE 349.703-1 RS, Rel. Orig. Min. Carlos Britto, Rel. p. Ac. Min Gilmar Mendes, julgado em 03/12/2008 (DJe n ${ }^{\circ} 104$, publicado em 05/06/2009.

${ }^{30} \mathrm{O}$ artigo $4^{\circ}$ do Decreto-Lei $n^{\circ}$ 911/1969, com a redação dada pela Lei ${ }^{\circ}$ 6. 071/1974, concedeu ao credor fiduciário ação de depósito fundada no contrato de alienação fiduciária em garantia, quando não encontre o bem ou não se ache na posse do devedor.

${ }^{31}$ A Constituição de 1969 ou a Constituição de 1967 com a redação da Emenda Constitucional n.1 de 1969, em seu artigo 153, §17, vedava a prisão por dívida, multa ou custas, salvo o caso de depositário infiel ou do responsável pelo inadimplemento de obrigação alimentar, na forma da lei. A Constituição de 1988 instituiu exceção semelhante em seu artigo $5^{\circ}$, inciso LXVII. 
enquanto o segundo traduz-se no crédito assegurado subsidiariamente pelo bem $^{32}$.

Após traçar essa distinção preliminar, o Relator perquiriu acerca do alcance do dispositivo constitucional que permitiria a prisão civil por dívidas. Em relação à matéria, a previsão constitucional de 1969 dispunha que "não haverá prisão civil por dívida, multa ou custas, salvo o caso do depositário infiel (...), na forma da lei, ao passo que, a Constituição de 1988 prevê que não haverá prisão civil por dívida, salvo (...) a do depositário infiel".

Para o Ministro Relator, instituiu-se a garantia de liberdade individual como regra, inclusive em casos de dívida, sendo-lhes exceções apenas as restritas hipóteses de inadimplemento de obrigação alimentícia e a do depositário infiel33, não tolerando interpretação expansiva ao devedor fiduciante, de modo concluiu que a ilegitimidade da prisão civil utilizando como parâmetro a CRFB, sem perquirir acerca das influências da Convenção Americana e do Pacto Internacional no ordenamento brasileiro.

De modo distinto ocorreu com o voto do Ministro Gilmar Mendes. Neste, embora se tenha dispensado a análise das teorias monista (kelseniana) e dualista (triepeliana), investigou-se a relação hierárquico-normativa entre os tratados internacionais e a CRFB, concluindo pelo caráter supralegal-infraconstitucional desses diplomas.

Inobstante, o Ministro consignou que a prisão civil do devedor-fiduciante viola o princípio da proporcionalidade, visto que o ordenamento jurídico prevê outros meios processuais-executórios, sendo tal prisão reprovada no crivo da proporcionalidade, bem como o Decreto-Lei $n^{\circ}$ 911/69 criou uma figura atípica de depósito, violando os limites do conteúdo semântico da expressão constitucional "depositário infiel", violando o princípio da reserva legal proporcional. Assim votou pelo desprovimento do recurso.

\footnotetext{
${ }^{32}$ Conferir o voto do Ministro Cezar Peluso, páginas 1108 a 1134 do RE em debate.

33 Registrou-se que a interpretação sobre o dispositivo deveria ser restritiva, na dúvida, solvida em prol da liberdade (exceptiones sunt strictissimae interpretationis/in dubio pro libertate). 
Em sequência, votaram a Ministra Cármen Lúcia, o Ministro Ricardo Lewandowski, o Min. Joaquim Barbosa34, o Min. Carlos Britto35 e o Min. Marco Aurélio, acompanhando aos votos do Relator e do Min. Gilmar Mendes pelo desprovimento do recurso. Após, o Ministro Celso de Mello em voto-vista defendeu a natureza constitucional dos tratados humanitários, desprovendo o recurso.

Em seguida, o Relator aditou seu voto reconhecendo caráter supralegal ou constitucional aos tratados humanitários, somente não comungando da tese da paridade normativa ordinária, sem ter-se comprometido definitivamente com uma específica teoria de primazia do direito internacional humanitário36.

Após, o Min. Menezes Direito proferiu voto-vista, reproduzindo o votovista presente no $\mathrm{HC} \mathrm{n}^{\circ} 87.585 / \mathrm{TO}$, o qual, tendo resgatado os votos dos Ministros, remontou-se à análise das correntes dualista e monista, concluindo pelo caráter de "lei especial" dos tratados humanitários.

Em última análise, justificou o Ministro Menezes Direito que considera mantida no ordenamento a prisão do depositário infiel judicial, uma vez que sua natureza específica de desrespeito a um múnus público permite sua prisão civil. Por fim, os Ministros Peluso e Gilmar Mendes confirmaram seus votos. Por unanimidade desproveu-se o recurso.

\section{ANÁLISE DAS TESES ACERCA DOS TRATADOS INTERNACIONAIS 4.1 O voto do Ministro Gilmar Mendes: a vencedora tese da supralegalidade}

Para o Ministro Gilmar Mendes, a promulgação da CRFB, sobretudo de seu artigo $5^{\circ}, \S 2^{\circ} 37$, ensejou a discussão sobre o status normativo dos tratados internacionais de direitos humanos, a qual se traduz em quatro correntes principais:

a) a vertente que reconhece a natureza supraconstitucional dos tratados e convenções em matéria de direitos humanos;

\footnotetext{
$34 \mathrm{O}$ qual ressaltou a prevalência da norma mais favorável ao indivíduo, conforme seu voto nas páginas 1199 a 1201, no caso de conflito entre as regras domésticas e as normas internacionais. 35 Que relembrou a natureza de norma de eficácia restringível do inciso LXVII do art. $5^{\circ}$ da Constituição da República Federativa do Brasil (voto presente nas páginas 1202 a 1206 do RE 466.343-1/SP).

${ }^{36}$ Cf. página 1282 do RE $466.343-1 /$ SP.

$37 \mathrm{CRFB}$, art. $5^{\circ}, \S 2^{\circ}$ : "Os direitos e garantias expressos nesta Constituição não excluem outros decorrentes do regime e dos princípios por ela adotados, ou dos tratados internacionais em que a República Federativa do Brasil seja parte.”

Revista de Direito Internacional do Programa de Pós-Graduação em Direito da UERJ 81
} 
b) o posicionamento que atribui caráter constitucional a esses diplomas internacionais;

c) a tendência que reconhece o status de lei ordinária a esse tipo de documento internacional;

d) por fim, a interpretação que atribui caráter supralegal aos tratados e convenções sobre direitos humanos. ${ }^{38}$

No que toca à vertente da supraconstitucionalidade, segundo o voto em análise, entende-se que nem uma emenda à constituição teria poder para suprimir a norma internacional humanitária. Para o voto:

É de ser considerada, no entanto, a dificuldade de adequação dessa tese à realidade de Estados que, como o Brasil, estão fundados em sistemas regidos pelo princípio da supremacia formal e material da Constituição (...). Entendimento diverso anularia a própria possibilidade do controle da constitucionalidade desses diplomas internacionais.

Como deixou enfatizado o Supremo Tribunal Federal ao analisar o problema, "assim como não o afirma em relação às leis, a Constituição não precisou dizer-se sobreposta aos tratados: a hierarquia está ínsita em preceitos inequívocos seus (...)”.39

Nessa esteira, o procedimento constitucional de aprovação e promulgação de tratados e sua submissão à jurisdição constitucional expressam a supremacia da Constituição sobre os mesmos, de modo que, no exercício do treaty-making power, os poderes públicos brasileiros conformam-se ao procedimento formal previsto na Constituição, bem como ao seu conteúdo material (direitos fundamentais). Somam-se tais considerações à atribuição de jurisdição constitucional concentrada no STF sobre os diplomas internacionais.

O posicionamento que atribui caráter constitucional aos tratados humanitários, segundo o voto em tela, assenta-se sobre o $\S 2^{\circ}$ do art. $5^{\circ}$ da CRFB, o qual se apresentaria como uma cláusula aberta de recepção dos direitos plasmados em tratados internacionais humanitários, tendo, a partir da ratificação (sem qualquer interpositio legislatoris), aplicabilidade imediata, por força do $\S 1^{\circ}$ do artigo $5^{\circ}$ da CRFB, e força constitucional.

Com efeito, a matéria especial dos tratados internacionais de direitos humanos estaria incorporada à Constituição da República Federativa do Brasil, restando aos tratados comuns a estatura infraconstitucional. Para essa tese:

eventuais conflitos entre o tratado e a Constituição deveriam ser resolvidos pela aplicação da norma mais favorável à vítima, titular do direito, tarefa hermenêutica da qual estariam incumbidos os tribunais

${ }^{38}$ Como foi registrado na página 1137 do RE 466.343-1/SP (página 3 do voto do Ministro Gilmar Mendes).

39 Cf. Voto do Ministro Gilmar Mendes, página 1139 do RE (página 5 do voto). 
nacionais e outros órgãos de aplicação do direito. Dessa forma, o Direito Interno e o Direito Internacional estariam em constante interação na realização do propósito convergente e comum de proteção dos direitos e interesses do ser humano ${ }^{40}$.

Objetou o Ministro contra tal corrente a inserção do $\S 3^{\circ}$ ao $\operatorname{artigo~} 5^{\circ}$ da CF41, o qual se trata de uma

declaração eloquente de que os tratados já ratificados pelo Brasil, anteriormente à mudança constitucional, e não submetidos ao processo legislativo especial de aprovação no Congresso Nacional, não podem ser comparados às normas constitucionais ${ }^{42}$.

Diante disso, observa-se um caráter especial dos tratados humanitários em relação aos demais diplomas internacionais, o que acena para a insuficiência da tese da legalidade ordinária, preconizada pela jurisprudência do STF43. Tal tese, concebida com o julgamento do RE $n^{\circ}$ 80.004/SE, advogava que os efeitos de um ato normativo internacional poderiam ser modificados pela lei nacional posterior, sendo que eventuais conflitos resolver-se-iam pela regra geral de solução antinômica lex posterior derrogat legi priori (afastando sua aplicação).

Ressalta o Ministro que, já após a CRFB de 1988, o STF voltou a discutir a matéria no $\mathrm{HC} \mathrm{n}^{\circ} 72.131 / \mathrm{RJ}$ (de 1995), tendo como foco a prisão civil do devedor fiduciário, reafirmando a tese da legalidade ordinária ou paridade normativa entre diplomas internacionais e leis nacionais, mas, reconhecendo que o Pacto de São José da Costa Rica, por ser lei geral, não revogaria o especial Decreto-Lei ${ }^{\circ}$ $911 / 69^{44}$.

Com efeito, o Ministro questionou se, "no contexto atual, em que se pode observar a abertura cada vez maior do Estado constitucional a ordens jurídicas supranacionais de proteção de direitos humanos, essa jurisprudência não teria se tornado completamente defasada" 45 . Assim se inseriu, no julgamento do RE $\mathrm{n}^{\mathrm{o}}$ 466.343-1/SP, a tese da supralegalidade dos tratados internacionais de direitos humanos no Brasil.

${ }^{40}$ Cf. Voto do Ministro Gilmar Mendes, página 1142 do RE (página 8 do voto).

${ }^{41} \mathrm{CRFB}$, art. $5^{\circ}, \S 3^{\circ}$ : "Os tratados e convenções internacionais sobre direitos humanos que forem aprovados, em cada Casa do Congresso Nacional, em dois turnos, por três quintos dos votos dos respectivos membros, serão equivalentes às emendas constitucionais" (incluído pela Emenda Constitucional $\mathrm{n}^{0} 45$, de 2004).

$4^{2} \mathrm{Cf}$. Voto do Ministro Gilmar Mendes, página 1144 do RE (página 10 do voto).

43 Como se registrou no RE no 80.004/SE (Min. Rel. Xavier de Albuquerque, julgado em 1/6/77, DJ de 29/12/77), $\mathrm{HC} \mathrm{n}^{\circ}$ 72.131/RJ (Min. Rel. Marco Aurélio, DJ 1/8/2003), ADI-MC nº 1.480/DF (Rel. Min. Celso de Mello, DJ 18/5/2001), dentre outros.

44 Cf. voto do Ministro Gilmar Mendes, páginas 1146 e 1447 do RE (páginas 12 e 13 do voto).

45 Idem, ibidem.

Revista de Direito Internacional do Programa de Pós-Graduação em Direito da UERJ 
Tendo em vista o enquadramento do Brasil como "Estado Constitucional Cooperativo"46, no qual o Estado disponibiliza-se como referência para os outros da mesma comunidade (ganhando relevo o papel dos direitos humanos), a cooperação entre os Estados promove a coexistência internacional pacífica, bem como o enfraquecimento dos limites entre o interno e externo, gerando o entendimento da prevalência do direito comunitário.

Sob tal perspectiva, o aspecto ideal-moral conduz à concepção cooperativa de Estado, de modo a:

exigir dos atores da vida sócio-política do Estado uma contribuição positiva para a máxima eficácia das normas das Constituições modernas que protegem a cooperação internacional amistosa como princípio vetor das relações entre os Estados Nacionais e a proteção dos direitos humanos como corolário da própria garantia da dignidade da pessoa humana ${ }^{47}$.

Nessa esteira, é possível observar na Constituição da República Federativa do Brasil quatro disposições que remetem o intérprete para realidades normativas relativamente diferenciadas em face da concepção tradicional do direito internacional público: o parágrafo único do art. $4^{\circ} 48, \mathrm{o} \$ 2^{\circ} 49$ do art. $5^{\circ}$ e os $\S \S 3^{\circ} \mathrm{e} 4^{\circ} 5^{\circ}$ do art. $5^{\circ}$ (incluídos pela $\mathrm{EC} \mathrm{n}^{\circ} 45 / 04$ ). Nessa linha, segundo o Ministro Gilmar Mendes, alguns países já avançaram em inserirem-se em contextos supranacionais, reservando lugar especial aos tratados em seu ordenamento51.

Tais dados revelam, consequentemente, uma "tendência contemporânea do constitucionalismo mundial de prestigiar as normas internacionais destinadas à proteção do ser humano" 52 . Ademais, a tese da legalidade ordinária, na medida

\footnotetext{
46 Nesse contexto, os motivos que conduzem à concepção de um Estado cooperativo são complexos. Porém, identifica o Ministro, ao menos, os aspectos sociológico-econômico e idealmoral como contributivos.

47 Cf. voto do Ministro Gilmar Mendes, páginas 1148 e 1449 do RE (páginas 14 e 15 do voto).

${ }^{48}$ CRFB: artigo $4^{\circ}$ : "A República Federativa do Brasil rege-se nas suas relações internacionais pelos seguintes princípios: (...) Parágrafo único. A República Federativa do Brasil buscará a integração econômica, política, social e cultural dos povos da América Latina, visando à formação de uma comunidade latino-americana de nações."

$49 \mathrm{CRFB}$, art. $5^{\circ}, \S 2^{\circ}$ : "Os direitos e garantias expressos nesta Constituição não excluem outros decorrentes do regime e dos princípios por ela adotados, ou dos tratados internacionais em que a República Federativa do Brasil seja parte.”

$5^{\circ} \mathrm{CRFB}$, art. $5^{\circ}, \S 3^{\circ}$ : "Os tratados e convenções internacionais sobre direitos humanos que forem aprovados, em cada Casa do Congresso Nacional, em dois turnos, por três quintos dos votos dos respectivos membros, serão equivalentes às emendas constitucionais." $\mathrm{CF}$, art. $5^{\circ}$, §4 $4^{\circ}$ : "O Brasil se submete à jurisdição de Tribunal Penal Internacional a cuja criação tenha manifestado adesão" (incluídos pela Emenda Constitucional no 45, de 2004).

${ }^{51}$ Tais como Paraguai (artigo $9^{\circ}$ de sua Constituição), Argentina (artigo 75, inciso 24 de sua Constituição), Uruguai (artigo $6^{\circ}$ de sua Constituição).

$5^{2}$ Cf. voto do Ministro Gilmar Mendes, páginas 1151 do RE (páginas 17 do voto). 
em que permite o descumprimento unilateral de um acordo internacional, viola princípios fixados na Convenção de Viena sobre o Direito dos Tratados de 1969 (art. 27), da qual o Brasil é signatário.

Assim, aflora o atributo da supralegalidade como consequência inafastável. Noutros termos, os tratados humanitários

não poderiam afrontar a supremacia da Constituição, mas teriam lugar especial reservado no ordenamento jurídico. Equipará-los à legislação ordinária seria subestimar o seu valor especial no contexto do sistema de proteção dos direitos da pessoa humana53.

Tal compreensão, esboçada anteriormente no STF em sede do RHC $\mathrm{n}^{\circ}$ 79.785-RJ pelo Min. Rel. Sepúlveda Pertence, possui assento na Constituição da Alemanha (artigo 25), na Constituição da França de 1958 (art. 55) e Constituição da Grécia de 1975 (art. 28). Não obstante, em matéria de direito tributário, vige o princípio da prevalência do direito internacional sobre o direito interno legal, por força do art. 98 do Código Tributário Nacional54, demonstrando patente incongruência nas concepções tradicionais brasileiras55.

Desta sorte, o caráter especial dos tratados humanitários impõe reconhecer que sua internalização no ordenamento (via ratificação), tem o condão de paralisar a eficácia jurídica de toda e qualquer disciplina normativa infraconstitucional com ela conflitante, de modo que a previsão constitucional da prisão civil do depositário infiel não foi revogada, mas deixou de ter aplicabilidade, uma vez paralisados os dispositivos legais que a disciplinavam.

Conclui assim o Ministro:

Enfim, desde a adesão do Brasil, no ano de 1992, ao Pacto Internacional dos Direitos Civis e Políticos (art. 11) e à Convenção Americana sobre Direitos Humanos - Pacto de San José da Costa Rica (art. $7^{\circ}$, 7), não há base legal para aplicação da parte final do art. $5^{\circ}$, inciso LXVII, da Constituição, ou seja, para a prisão civil do depositário infiel.

De qualquer forma, o legislador constitucional não fica impedido de submeter o Pacto Internacional dos Direitos Civis e Políticos e a Convenção America Americana sobre Direitos Humanos - Pacto de San José da Costa Rica, além de outros tratados de direitos humanos, ao procedimento especial de aprovação previsto no art. $5^{\circ} \S 3^{\circ}$, da

53 Cf. voto do Ministro Gilmar Mendes, páginas 1154 do RE (páginas 20 do voto).

54 CTN (Lei ${ }^{\circ} 5.172$ de 1966), art. 98: "Os tratados e as convenções internacionais revogam ou modificam a legislação tributária interna, e serão observados pela que lhes sobrevenha."

55 Cf. voto do Ministro Gilmar Mendes, páginas 1156 do RE (páginas 22 do voto): "admite-se o caráter especial e superior (hierarquicamente) dos tratados sobre matéria tributária em relação à legislação infraconstitucional, mas quando se trata de tratados sobre direitos humanos, reconhece-se a possibilidade de que seus efeitos sejam suspensos por simples lei ordinária."

Revista de Direito Internacional do Programa de Pós-Graduação em Direito da UERJ $\quad 85$ 
Constituição, tal como definido pela $\mathrm{EC} \mathrm{n}^{\circ}$ 45/2004, conferindo-lhes status de emenda constitucional.

\title{
4.2 Voto do Ministro Celso de Mello: status constitucional dos tratados humanitários
}

Por sua vez, em seu voto-vista, o Min. Celso de Mello registrou que a matéria envolve discussão em torno do alcance e da precedência dos direitos fundamentais da pessoa humana, impondo o exame da internacionalização dos mesmos e as relações entre o direito nacional e o direito internacional dos direitos humanos em face do $\S 3^{\circ}$ do art. $5^{\circ}$ da CRFB. Com efeito, o valor ético fundamental da pessoa humana figura como dado axiológico essencial e:

\begin{abstract}
ao contrário dos padrões ortodoxos consagrados pelo direito internacional clássico, os tratados e convenções, presentemente, não mais consideram a pessoa humana como um sujeito estranho ao domínio de atuação dos Estados no plano externo.

$\mathrm{O}$ eixo de atuação do direito internacional público contemporâneo passou a concentrar-se, também, na dimensão subjetiva da pessoa humana, cuja essencial dignidade veio a ser reconhecida, em sucessivas declarações e pactos internacionais, como valor fundante do ordenamento jurídico sobre o qual repousa o edifício institucional dos Estados nacionais. 56
\end{abstract}

Diante de tais considerações, os tratados humanitários desempenham papel relevante na afirmação dos direitos básicos da pessoa humana, dentre os quais o de não sofrer prisão por dívida. Nessa esteira, a Constituição Federal promove tal vedação, excepcionando-a quanto à obrigação alimentícia e ao depositário infiel. Assim, sem a lei veiculadora de sua disciplina, torna-se juridicamente inviável recorrer-se a esse meio coercitivo, tendo em vista a não vinculatividade do legislador ordinário às exceções meramente permissivas.

Nesse sentido, conforme vota o Min. Celso de Mello, o legislador não se acha compelido a regular a prisão civil, obtendo relativa liberdade decisória de “(a) disciplinar ambas as hipóteses (inexecução de obrigação alimentar e infidelidade depositária), (b) abster-se, simplesmente de instituir a prisão civil e (c) instituí-la em apenas uma das hipóteses facultadas pela Constituição" 57 . Tal espaço decisório pode, como ocorreu, ser preenchido pela normatividade internacional, surgindo a questão da hierarquia das fontes.

\footnotetext{
${ }^{6}$ Cf. voto do Ministro Celso de Mello, página 1221 do RE em tela (página 11 de seu voto). 57 Idem, p. 1227 (p. 17 do voto). 
Para o Ministro, a definição da posição hierárquica dos tratados humanitários em face do direito interno merece profunda análise. Há o desenvolvimento da tese de sua supralegalidade-infraconstitucionalidade (como apresentou o Min. Gilmar Mendes), bem como de sua qualificação materialmente constitucional pela composição do "bloco de constitucionalidade" 58 , consoante permite o $\S 2^{\circ}$ do art. $5^{\circ}$ da CRFB. Dessarte, posicionou-se pela natureza constitucional de tais normas, de modo a observar-lhes três situações:

(1) tratados internacionais de direitos humanos celebrados pelo Brasil (ou aos quais o nosso País aderiu), e regularmente incorporados à ordem interna, em momento anterior ao da promulgação da Constituição de 1988 (tais convenções internacionais revestem-se de índole constitucional, porque formalmente recebidas, nessa condição, pelo $\S 2^{\circ}$ do art. $5^{\circ}$ da Constituição);

(2) tratados internacionais de direitos humanos que venham a ser celebrados pelo Brasil (ou aos quais o nosso País venha a aderir) em data posterior à da promulgação da $\mathrm{EC} \mathrm{n}^{\circ}$ 45/2004 (essas convenções internacionais, para se impregnarem de natureza constitucional, deverão observar o "iter" procedimental estabelecido pelo $\$ 3^{\circ} \mathrm{do}$ art. $5^{\circ}$ da Constituição); e

(3) tratados internacionais de direitos humanos celebrados pelo Brasil (ou aos quais o nosso País aderiu) entre a promulgação da Constituição de 1988 e a superveniência da EC n ${ }^{\circ} 45 / 2004$ (referidos tratados assumem caráter materialmente constitucional, porque essa qualificada hierarquia jurídica lhes é transmitida por efeito de sua inclusão no bloco de constitucionalidade (...).59

Portanto, não haveria a possibilidade de denúncia pela vontade do Executivo ou sua imposição por lei ordinária do Congresso Brasileiro. Por força do fenômeno da recepção de normas anteriores à Constituição da República Federativa do Brasil, o qual somente verifica compatibilidade material, sob tais premissas, os tratados humanitários em destaque teriam status constitucional, exigindo alteração via emenda constitucional e respeito à vedação ao retrocesso social.

Deste modo, subsiste enquanto parâmetro conformador e supremo do ordenamento jurídico a Constituição brasileira (CRFB), apresentando-se a Convenção Americana e o Pacto Internacional enquanto normas com status constitucional, ao passo que, os tratados não-humanitários localizam-se em

${ }^{8}$ Cf. Celso Lafer apud Celso de Mello (p. 1236 do RE 466.343-1/SP): "conjunto normativo que contém disposições, princípios e valores que, no caso, em consonância com a Constituição de 1988, são materialmente constitucionais, ainda que estejam fora do texto da Constituição documental. O bloco de constitucionalidade é, assim, a somatória daquilo que se adiciona à Constituição escrita, em função dos princípios e valores nela consagrados."

59 Cf. voto do Min. Celso de Mello, página 1237 e 1238 do RE em tela (páginas 27 e 28 do voto).

Revista de Direito Internacional do Programa de Pós-Graduação em Direito da UERJ 87 
paridade com a legislação ordinária, de modo que a prisão civil do devedor fiduciante não encontraria substrato de validade.

\subsection{O voto do Ministro Menezes Direito: o caráter especial dos tratados humanitários}

Por fim, examinou a natureza e o status dos tratados humanitários, o Min. Menezes Direito. Considerou o Ministro que, "historicamente, os autores dividiam-se entre as escolas monista e dualista, havendo ainda quem tentasse apresentar conciliação entre elas"6o.

Nessa esteira, o dualismo (de Triepel), segundo o voto do Ministro Menezes Direito ${ }^{61}$, apresentava que o direito internacional e o direito interno são dois sistemas iguais, independentes e separados, que não se confundem, sendo diversos seus sujeitos de direito e suas estruturas. Para o monismo, segundo se relata no voto, consubstanciaram-se duas vertentes, uma que confere prevalência ao direito interno, e outra que faz o mesmo ao direito internacional.

Na primeira vertente do monismo, conforme cita o voto em análise ${ }^{62}$, terse-ia a concepção de Hegel, para o qual o Estado era uma síntese de contradições verificadas na realidade, gozando de uma soberania absoluta, de modo que o direito internacional retirava sua força do direito interno. Quanto à segunda vertente, observa-se a Escola de Viena que propunha a prevalência do direito internacional, considerando a soberania um conceito relativo.

Entre os conciliadores, há destaque para doutrinadores espanhóis, os quais introduziram a coordenação do direito natural. Para Gustav Adolf Walz, conforme apresenta o Ministro, "o direito internacional tanto pode ser originário, isto é, possuir autoridade imediata sobre estados e entidades análogas, como derivado, isto é, possuir validade interna em decorrência de uma norma de direito interno"63.

Diante dessas correntes, o Ministro Menezes Direito entendia não ser razoável considerar primazia absoluta ao direito interno ou ao internacional, posicionando-se pela compreensão de que "o direito internacional e o direito

\footnotetext{
${ }^{60}$ Cf. voto do Min. Menezes Direito, página 1294 do RE (página 9 de seu voto).

${ }^{61}$ Idem, ibidem.

${ }^{62}$ Idem, ibidem.

63 Idem, ibidem.

88

Cosmopolitan Law Journal, v. 2, n. 1, jun. 2014, p. 73-94
} 
interno são direitos com uma mesma substância de valor e conformação"64. Porém, ao tratar do Direito das Gentes (direito internacional dos direitos humanos), o Ministro procurou estabelecer-lhe um padrão especial.

Aderiu, assim, à ultrapassagem da antiga jurisprudência da equiparação com as leis ordinárias, com vistas a uma nova classificação dessas espécies normativas internacionais, como registrou:

Parto, assim, da classificação que separa nas espécies normativas internacionais todos aqueles relativos aos direitos humanos dos demais. O meu fundamento é a natureza supra-estatal desses direitos, os quais, portanto, não são dependentes do reconhecimento pelo direito interno, cabendo-lhe apenas e unicamente declará-los. Se os direitos do homem existem pela natureza mesma da pessoa humana, os estados nacionais que dele se ocupam fazem-no em função de declarações positivadas, o que significa a pré-existência desses direitos com relação ao direito interno. Essa natureza especial do [sic] ser do homem é que dá dimensão própria aos direitos humanos, autorizando no plano das relações entre o direito interno e o direito internacional uma relação que põe relevo no primeiro, não no segundo. $\mathrm{O}$ homem não está limitado ao estado nacional e, portanto, seus direitos também não estão. Ele está na dimensão da humanidade que ultrapassa por definição a regência doméstica. Daí que teremos de construir na operação jurídica dos planos estatais uma incorporação que guarde essa dimensão. ${ }^{65}$

Sob tais considerações, o Ministro Menezes Direito observou a existência de duas possibilidades, ambas já expostas: a do Min. Celso de Mello (constitucionalidade) e a do Min. Gilmar Mendes (infraconstitucionalidadesupralegalidade). Para o Min. Menezes Direito, a incorporação automática dos tratados humanitários com status constitucional violentaria a disciplina do constituinte brasileiro, bem como impossibilitaria o controle de constitucionalidade das normas internacionais.

Deste modo, o Ministro propõe uma solução já esboçada no STF (pelo Min. Orozimbo Nonato, na $\left.\mathrm{AC} \mathrm{n}^{\circ} 9.587 / \mathrm{DF}, 21 / 8 / 1951\right)$, a de conferir-lhes o status de "leis especiais". Tais atos não seriam supralegais, mas especiais, ou seja:

atos de hierarquia diferenciada, na medida em que oriundos de um plano que esta além, pela própria natureza do seu conteúdo substantivo, da hierarquização legislativa doméstica. Eles ficam no plano legal, mas com hierarquia superior, porquanto ingressaram de forma diferente da produção normativa doméstica. ${ }^{66}$

${ }^{64}$ Idem, p. 1295 (p. 10).

65 Idem, p. 1300-1301 (p. 15-16).

66 Idem, p. 1303 (p. 18).

Revista de Direito Internacional do Programa de Pós-Graduação em Direito da UERJ 
Destarte, a Convenção e o Pacto ingressam na ordem doméstica com hierarquia especial, mas infraconstitucional, suspendendo a eficácia das disposições legais de equiparação entre o devedor fiduciante e o depositário infiel, bem como daquelas que permitem a prisão civil do depositário infiel de origem contratual.

\section{ANÁLISE CRÍTICA DO ENTENDIMENTO DO SUPREMO TRIBUNAL FEDERAL À LUZ DA DOUTRINA DO DIREITO INTERNACIONAL}

Diante das premissas teóricas assentadas, cabe retomar-se o julgamento do RE 466.343-1/SP. Em relação aos tratados internacionais de direitos humanos no Brasil, foram defendidas três teses no julgamento: a supralegalidadeinfraconstitucionalidade (Min. Gilmar Mendes - tese vencedora), status constitucional (mas legalidade ordinária aos tratados comuns - Min. Celso de Mello), caráter especial (plano da legalidade, mas com hierarquia qualificada Min. Menezes Direito).

Tais teses, a despeito de suas variações, tiveram como preocupação central submeter a normatividade humanitária internacional - no caso, a Convenção Americana sobre Direitos Humanos e o Pacto Internacional sobre Direitos Civis e Políticos, ao paradigma da Constituição brasileira (CRFB), seja por submissão (supralegalidade/lei especial) ou por paridade normativa (recepção com status constitucional).

De tal forma, pode-se observar que o STF demonstrou concepção que confere primazia ao direito interno (pela supremacia da Constituição Federal brasileira), tendo, porém, como parâmetro influências do sistema internacional sobre o nacional, após a devida incorporação interna, como expõe a literatura:

A Suprema Corte brasileira tem exigido, após a aprovação do tratado pelo Congresso Nacional e à troca dos respectivos instrumentos de ratificação - o que, de resto, a prática brasileira já segue há vários anos -, que seja o tratado internacional promulgado internamente, por meio de um decreto de execução presidencial (não se exigindo seja o tratado "transformado" em lei interna). Para o Supremo Tribunal Federal tal decreto executivo, enquanto momento culminante do processo de incorporação dos tratados ao sistema jurídico brasileiro, é manifestação essencial e insuprimível, considerando-se seus três efeitos básicos: a) a promulgação do tratado internacional; b) a publicação oficial de seu texto; e c) a executoriedade do ato 
internacional. Nesse sentido, poder-se-ia dizer que o STF tem assumido posição dualista moderada. ${ }^{67}$

Se ainda no paradigmático RE $n^{\circ} 80.004 / \mathrm{SE}$ já se compreendeu que o STF filiava-se ao monismo moderado ${ }^{68}$, com a equiparação dos tratados às leis ordinárias, implicando em revogação por sucessão cronológica, com o julgamento do RE 466.343-1/SP o STF, sobretudo em relação à tese vencedora, manteve como pressuposto o devido processo de internalização dos tratados. Desse modo, observa-se o paradigma dualista moderado, embora com qualificação sui generis para a normatividade internacional humanitária.

Isto se explica porque o monismo moderado, tal como é aplicado no Brasil, representa o segundo momento do dualismo,

quando a norma já incorporada poderá ou não colidir com a norma interna. Isso é falso problema, porque a norma incorporada segundo o sistema dualista, ao entrar no ordenamento jurídico, passa a pertencer a este e enquadrar-se nas hipóteses de análise pertinente às demais leis ${ }^{69}$.

Vale observar, assim, que "ao estabelecer a necessidade imperiosa de incorporação, independentemente da posição que assumirá posteriormente a norma, adota o direito brasileiro certa forma de dualismo, na modalidade moderada"70.

Em verdade, torna-se difícil inserir o entendimento esboçado pelo STF em dualismo moderado ou monismo nacionalista com caráter moderado, sob as feições teóricas perfeitamente delineadas. Isto porque o STF exige a internalização dos tratados humanitários, o que ocorre por procedimento complexo (e não estritamente por lei interna) e porque tais diplomas ficam imunes à legislação ordinária, mas sob a compatibilização com a Constituição Federal.

Assim, com a devida cautela teórica, é possível dizer que o Brasil encontrase sob a perspectiva de um dualismo moderado que confere primazia (supremacia) ao direito interno constitucional, mas cujos tratados internacionais de direitos humanos internalizados não podem ser revogados pela legislação

\footnotetext{
${ }^{67}$ Cf. MAZZUOLI, op.cit., p. 91.

${ }^{68}$ Cf. ACCIOLY; SILVA; CASELLA, op. cit., p. 239.

69 Idem, ibidem.

70 Idem, ibidem.
} 
ordinária. Em verdade, os tratados paralisam a eficácia da lei comum interna, estando somente submissos à Constituição brasileira (CRFB).

Essa posição jurisprudencial (dualismo moderado com qualificação única dada à normatividade internacional humanitária) não se isenta de críticas. De acordo com a literatura71, critica-se a adoção de tal paradigma diante da negativa da compreensão pelo fundamento do direito na comunidade internacional (monismo internacionalista).

Admitir tal doutrina:

equivale a negar o fundamento de validade do Direito Internacional e, consequentemente, a sua própria existência como ramo da ciência jurídica, o que já é suficiente para qualificá-la como desprovida de fundamento. Ora, não existe Estado isolado, flutuando no espaço ou vácuo. Todos eles se encontram dentro de uma sociedade internacional. Se é dessa sociedade que florescem as normas que estruturam o sistema internacional e regulam a conduta dos Estados em suas relações recíprocas, também é dessa mesma sociedade que nascem os limites às regras do Direito interno. O Direito é uma superestrutura que depende de uma infraestrutura. Se esta é alterada, aquela será abalada, causando desequilíbrios de diversas ordens. Para que tal não ocorra, basta admitir a supremacia do Direito Internacional frente aos ordenamentos internos. (...) Toda a normatividade extrai, pois, o seu fundamento de validade do ordenamento jurídico internacional. Consequentemente deve conformação e respeito para com este último. E como isto sucede? Adequando-se as normas do Direito interno aos mandamentos do Direito Internacional, do qual retira a razão de sua existência. ${ }^{72}$

O direito internacional, cujo fundamento está no pacta sunt servanda, nesse sentido, encontra-se supraelevado ao direito interno, servindo-lhe como fundamento de validade, bem como servindo-se dele para executar seus preceitos, o que impõe reconhecer uma relativização e redefinição da soberania dos Estados isolados, em favor da soberania da sociedade internacional73.

É de se questionar quais seriam, nessa esteira, os efeitos da tese da supralegalidade dos tratados internacionais de direitos humanos no Brasil. Observa-se que, de acordo com esse escalonamento sui generis, os tratados internacionais humanitários submetem-se à Constituição, permitindo seu controle perante ela (jurisdição constitucional). Ademais, inovam o sistema de

${ }^{71}$ Cf. MAZZUOLI, op. cit., p. 96-97; VERDROSS, 2013, p. 18-33.

${ }^{2}$ MAZZUOLI, op. cit., p. 96-97.

73 Cf. VERDROSS, op. cit., p. 22-33.

$92 \quad$ Cosmopolitan Law Journal, v. 2, n. 1, jun. 2014, p. 73-94 
controle da higidez normativa, inserindo o controle de convencionalidade das leis ordinárias, uma vez dado o caráter supralegal74.

E ainda, ao menos em tese, a noção de supralegalidade permitiria a modificação da aplicabilidade de tratado internacional humanitário pela alteração da Constituição brasileira (CRFB), o que se apresenta inaceitável em direito internacional, inclusive no ordenamento doméstico, tendo em vista a ratificação e publicização via decreto da Convenção de Viena sobre o Direito dos Tratados 75 .

\section{CONCLUSÃo}

O julgamento do RE 466.343-1/SP é um marco no avanço da jurisprudência da suprema corte brasileira para a superelevação do direito internacional no âmbito interno. Se antes o Supremo Tribunal Federal equiparava os tratados internacionais à legislação ordinária interna, demonstrando pouco apreço pelas deliberações da comunidade internacional, hoje o STF compreende que a normatividade internacional humanitária está um nível superior à legislação doméstica brasileira comum.

Contudo, a supralegalidade dos tratados internacionais de direitos humanos foi associada a uma infraconstitucionalidade, observando como paradigma a primazia do direito constitucional interno, o que, ao menos em tese, traz a possibilidade da alteração unilateral ou do inadimplemento internacional no Brasil pela modificação da Constituição (CRFB).

Diante dos marcos teóricos do direito internacional - dualismo radical, dualismo moderado, monismo nacionalista, monismo internacionalista, monismo internacionalista dialógico -, a posição do STF apresenta-se pouco subsumível, situando-se numa qualificação sui generis: somente aceita a

\footnotetext{
74 Controle da convencionalidade "significa falar em compatibilidade vertical das normas do direito interno com as convenções internacionais de direitos humanos em vigor no país. Significa, também, falar em técnica judicial de compatibilização vertical com tais preceitos internacionais de direitos humanos" (MAZZUOLI, Valério de Oliveira. O controle jurisdicional da convencionalidade das leis. São Paulo: Editora Revista dos Tribunais, 2009, p. 17).

75 A Convenção de Viena sobre o Direito dos Tratados de 1969 foi aprovada pelo Decreto Legislativo $\mathrm{n}^{\circ} 496 / 2009$ e promulgada pelo Decreto presidencial $\mathrm{n}^{\circ}$ 7.030/2009. Seus artigos 26 e 27 são pertinentes à matéria: "Art. 26. Pacta sunt servanda. Todo tratado em vigor obriga as partes e deve ser cumprido por elas de boa fé; Art. 27. Direito Interno e Observância de Tratados. Uma parte não pode invocar as disposições de seu direito interno para justificar o inadimplemento de um tratado. Essa regra não prejudica o art. 46." Disponível em: <http://www.planalto.gov.br/ccivil_03/_Ato2007-2010/2009/Decreto/D703o.htm>. Acesso em: 29/05/2014.
}

Revista de Direito Internacional do Programa de Pós-Graduação em Direito da UERJ 93 
aplicação do direito internacional no âmbito doméstico se houver internalização (dualismo moderado), eleva o patamar dos diplomas humanitários (monismo internacionalista), mas os submete à Constituição da República (monismo nacionalista).

Desse modo, a compreensão do STF acaba por desconsiderar a corrente que confere primazia ao direito internacional (como fundamento último do direito interno) e coloca em risco o fiel cumprimento dos compromissos internacionais pelo Brasil, uma vez teoricamente possível que a Constituição brasileira (CRFB) afaste os moldes normativos pactuados pela comunidade internacional.

\section{REFERÊNCIAS}

ACCIOLY, Hildebrando; SILVA, G. E. do Nascimento e; CASELLA, Paulo Borba. Manual de Direito Internacional Público. 20 ed. São Paulo: Saraiva, 2012.

BRASIL. Convenção Americana Sobre Direitos Humanos. Disponível em: $<\quad$ http://www.planalto.gov.br/ccivil_03/decreto/1990-1994/anexo/and67892.pdf >. Acesso em: 29/05/2014.

BRASIL. Convenção de Viena Sobre o Direito dos Tratados. Disponível em: $\quad<\quad$ http://www.planalto.gov.br/ccivil_03/_Ato20072010/2009/Decreto/D703

o.htm > . Acesso em: 29/05/2014.

BRASIL. Pacto Internacional dos Direitos Civis e Políticos. Disponível em: < http://www.planalto.gov.br/ccivil_03/decreto/1990-1994/Do592.htm >. Acesso em: 29/05/2014.

BRASIL. SUPREMO TRIBUNAL FEDERAL. Recurso Extraordinário 466.343-1/São Paulo. Disponível em: < http://redir.stf.jus.br/paginadorpub/paginador.jsp?docTP= AC\&docID $=595444>$. Acesso em 29/05/2014.

MAZZUOLI, Valério de Oliveira. Curso de Direito Internacional Público. $8^{\text {a }}$ ed. rev., atual. e ampl. São Paulo: Revista dos Tribunais, 2014.

Leis. São Paulo: Editora Revista dos Tribunais, 2009. O Controle Jurisdicional da Convencionalidade das

VERDROSS, Alfred. O Fundamento do Direito Internacional. Revista de Direito Internacional. Uniceub. Brasília, v. 10, n. 2, 2013. 